\title{
The Origin of Kimberlite
}

\author{
Peter J. Wyllie \\ Department of Geophysical Sciences, University of Chicago, Chicago, Illinois 60637
}

\begin{abstract}
A new diapiric model for kimberlite genesis takes into account recent interpretations of peridotite$\mathrm{CO}_{2}-\mathrm{H}_{2} \mathrm{O}$ melting relationships. A minor thermal perturbation at depth might trigger release of reduced vapors with major components $\mathrm{C}-\mathrm{H}-\mathrm{O}$. Where these volatile components cross the estimated solidus boundary near $260 \mathrm{~km}$, partial melting occurs, the density inversion causes diapiric uprise along adiabats, and the partially melted diapirs begin to crystallize at 100 to $80-\mathrm{km}$ depth, where they reach a temperature maximum (thermal barrier) on the solidus. The released vapor enhances the prospects for crack propagation through overlying lithosphere in tension, and this could produce an initial channel to the surface. Magma separation could then occur from progressively greater depths, releasing $\mathrm{CO}_{2}$-undersaturated kimberlitic magma for independent uprise through the established conduit, quite unaffected by the thermal barrier on the solidus of peridotite- $\mathrm{CO}_{2}-\mathrm{H}_{2} \mathrm{O}$. Cooler diapirs would cross the solidus at somewhat greater depth, solidifying to phlogopite-dolomite-peridotite with the release of aqueous solutions. These solutions are likely candidates for the mantle metasomatism commonly considered to be a precursor for the generation of kimberlites and other alkalic magmas. According to this model the metasomatism is a consequence of kimberlite magmatism rather than its precursory cause.
\end{abstract}

\section{INTRODUCTION}

In this paper honoring G. C. Kennedy I will use recent interpretations for melting relationships in the system peridotite- $-\mathrm{CO}_{2}-\mathrm{H}_{2} \mathrm{O}$ to develop a diapiric model for the origin of kimberlites, involving the leakage of volatile components from deep within the mantle.

Evidence for the occurrence of $\mathrm{CO}_{2}$ in the upper mantle and the ways in which it might be stored were reviewed by $I r$ ving and Wyllie [1973]. The evidence that $\mathrm{CO}_{2}$ is transported from the mantle by magmas and rocks yas reviewed by $W y l l i e$ [1977] and Eggler [1978]. Anderson [1975] and Wyllie [1979] summarized information about the compositions of gases emerging from the mantle and crust through volcanic action; $\mathrm{H}_{2} \mathrm{O}$ and $\mathrm{CO}_{2}$ are the most abundant components. It is established that kimberlites are derived from deep-seated upper mantle sources, and when kimberlites are emplaced in the crust, $\mathrm{CO}_{2}$ and $\mathrm{H}_{2} \mathrm{O}$ are important components. Therefore the system peridotite- $\mathrm{CO}_{2}-\mathrm{H}_{2} \mathrm{O}$ is relevant for the origin of kimberlites. However, the variation of temperature and oxygen fugacity with depth in various tectonic environments is an important but inadequately understood factor, crucial for the rigin of kimberlites and diamonds, as recognized by Kennedy nd Nordlie [1968].

\section{Phase Relationships for Peridotite- $\mathrm{CO}_{2}-\mathrm{H}_{2} \mathrm{O}$}

The partial melting of dolomite/magnesite-phlogopite-petite, with or without a $\mathrm{CO}_{2}-\mathrm{H}_{2} \mathrm{O}$ vapor phase, is generally idered to be a suitable source of kimberlite, or kimberlitemagmas. Selected phase relationships for peridotite- $\mathrm{CO}_{2}$ are illustrated in Figures 1 and 2 . These are partly sche, with experimental details and deductive approaches ted and critically reviewed by Mysen and Boettcher Eggler [1978], Eggler and Wendlandt [1979], Wyllie 1978, 1979], and Ellis and Wyllie [1980]. Invariant univariant lines, and divariant surfaces identified in Il system $\mathrm{CaO}-\mathrm{MgO}_{\mathrm{S}} \mathrm{SiO}_{2}-\mathrm{CO}_{2}-\mathrm{H}_{2} \mathrm{O}$ are represented in way for the system peridotite- $\mathrm{CO}_{2}-\mathrm{H}_{2} \mathrm{O}$, despite the iddition of components such as $\mathrm{FeO}$ and $\mathrm{Al}_{2} \mathrm{O}_{3}$ will me univariant reactions into divariant bands and

(c) 1980 by the American Geophysical Union.

80B0453.

/080B-0453\$01.00 points and surfaces will be changed accordingly. This simplification of the phase diagrams for peridotite- $\mathrm{CO}_{2}-\mathrm{H}_{2} \mathrm{O}$ has no significant effect on applications. Despite the paucity of experimental data for many of the reactions plotted in Figures 1 and 2 , the reactions are fairly well constrained up to pressures of $30 \mathrm{kbar}$. The specific phase boundaries are used to illustrate and interpret the types of processes that might occur in the upper mantle, with the understanding that precise depths and temperatures will need correction as additional experimental studies define the reactions more closely.

The solidus for peridotite with neither $\mathrm{H}_{2} \mathrm{O}$ or $\mathrm{CO}_{2}$ is given in Figure $1 a$ as a dashed line. Basaltic liquids are generated at temperatures above this line. The solidus is lowered through hundreds of degrees in the presence of $\mathrm{H}_{2} \mathrm{O}$, but it is established that the effect of $\mathrm{H}_{2} \mathrm{O}$ does not change the liquids toward kimberlite compositions. At pressures to more than 20 kbar the solubility of $\mathrm{CO}_{2}$ in the liquids remains very low, and the solidus curve for peridotite- $\mathrm{CO}_{2}$ is therefore depressed only slightly below that for peridotite. With increasing pressure, however, the solidus drops abruptly within a small pressure interval to the invariant point $Q_{1}$, where a subsolidus reaction curve for the formation of dolomite-peridotite reaches the solidus. It requires about $5 \% \mathrm{CO}_{2}$ to produce the maximum amount of dolomite from a normal peridotite (at the expense of clinopyroxene). The curve $Q_{1} N$ is the univariant curve for the beginning of melting of dolomite-peridotite in the presence of $\mathrm{CO}_{2}-\mathrm{H}_{2} \mathrm{O}$, with vapor composition buffered by the presence of dolomite. As shown by the curve $Q_{1} Q_{2} N$ in Figure $\mathrm{lc}$, the buffered vapor phase $(\mathrm{Vb})$ changes from $\mathrm{CO}_{2}$ at $Q_{1}$ to $\mathrm{H}_{2} \mathrm{O}$-rich compositions a few kilobars above $Q_{1}$. The composition of the liquids generated above $Q_{1} N$ range from carbonatitic to low- $-\mathrm{SiO}_{2}$, alkalic compositions through a wide range of temperatures at pressures above $\boldsymbol{Q}_{1}$.

The dashed line labeled $T_{\max }$ in Figure la is a temperature maximum on the solidus surface for peridotite- $\mathrm{CO}_{2}-\mathrm{H}_{2} \mathrm{O}$, which is represented also by a thermal barrier on liquidus paths through the system. This has significant consequences for the phase relationships of material with fixed composition, as discussed below [see Ellis and Wyllie, 1980].

The peridotite- $\mathrm{CO}_{2}$ solidus $P Q_{1}$ and the buffered dolomiteperidotite-Vb solidus $Q_{1} N$ are transferred from Figure $1 a$ to 

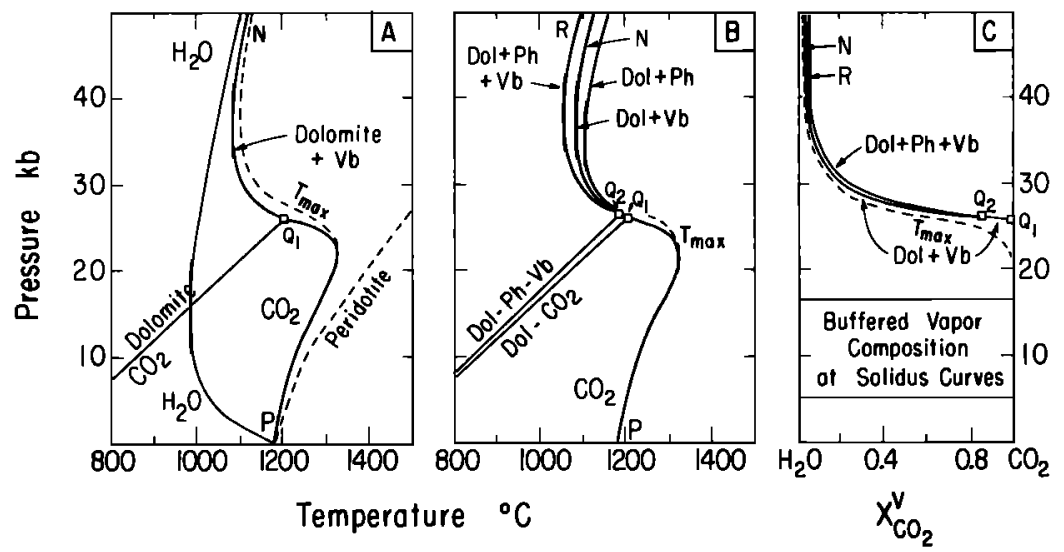

Fig. I. Selected reactions from the system peridotite- $\mathrm{CO}_{2}-\mathrm{H}_{2} \mathrm{O}$, in part schematic, with constraints described by Eggler [1978] and Wyllie [1977, 1978, 1979]. The numbers are based on the values adopted by Wyllie [1977, 1978]. The use of specific values of pressure and temperature, in order to maintain consistency from one diagram to another, does not imply accuracy. Precise values for many parts of this and following phase diagrams need experimental determination. Note in particular the three solidus curves at pressures above $Q_{1}$ Figure $1 b$ and the buffered vapor phase compositions (Vb) in Figure 1c. Ph is phlogopite, and $\mathrm{Dol}$ is dolomite solid solution.

1b. The small amount of potassium present in normal mantle peridotite is readily accommodated by amphibole within its stability field, but it may form phlogopite at higher pressures and temperatures. There are two subsolidus divariant surfaces for the dissociation of dolomite and phlogopite, respectively, in the system peridotite- $\mathrm{CO}_{2}-\mathrm{H}_{2} \mathrm{O}$, and these meet along the univariant buffered exchange reaction in Figure $1 b$, Dol-Ph$\mathrm{Vb}$, which terminates at the solidus at point $\boldsymbol{Q}_{2}$.

At higher pressures, there is an additional solidus curve $Q_{2} R$ for dolomite-phlogopite-peridotite- $\mathrm{Vb}$, with vapor composition slightly enriched in $\mathrm{CO}_{2}$ in comparison with the dolomite buffer, as shown in Figure 1c.

Although only about $0.02 \% \mathrm{H}_{2} \mathrm{O}$ can be stored in phlogopite in normal mantle peridotite [Ringwood, 1975, p. 225], metasomatic processes may introduce phlogopite. Under these circumstances the $\mathrm{H}_{2} \mathrm{O}$ and $\mathrm{K}_{2} \mathrm{O}$ concentrations in the mantle may locally reflect the phlogopite distribution, with no relationship to standard mantle compositions. For peridotite with all $\mathrm{CO}_{2}$ and $\mathrm{H}_{2} \mathrm{O}$ stored in carbonate or phlogopite, there is another solidus curve for vapor-absent dolomite-phlogopiteperidotite situated at slightly higher temperatures, as shown in Figure $1 b$ [Holloway and Eggler, 1976].

The reactions plotted in Figure 1 refer to univariant reactions applicable to a range of compositions in peridotite- $\mathrm{CO}_{2}-$ $\mathrm{H}_{2}$ O. For consideration of melting processes within the mantle we should consider the phase diagram for a particular composition.

$$
\begin{gathered}
\text { Peridotite WITH } \mathrm{CO}_{2} /\left(\mathrm{CO}_{2}+\mathrm{H}_{2} \mathrm{O}\right)=0.8 \\
\text { AND Low } \mathrm{CO}_{2}+\mathrm{H}_{2} \mathrm{O}
\end{gathered}
$$

The phase fields intersected by peridotite- $\mathrm{CO}_{2}-\mathrm{H}_{2} \mathrm{O}$ vary according to $\mathrm{CO}_{2} / \mathrm{H}_{2} \mathrm{O}$ and the total amount of $\mathrm{CO}_{2}+\mathrm{H}_{2} \mathrm{O}$. It requires about $0.4 \% \mathrm{H}_{2} \mathrm{O}$ to make the maximum possible amount of amphibole from normal mantle peridotite and about $5 \% \mathrm{CO}_{2}$ to make the maximum amount of dolomite. Assume a peridotite with less than these amounts of $\mathrm{H}_{2} \mathrm{O}$ and $\mathrm{CO}_{2}$ and a high ratio of $\mathrm{CO}_{2} / \mathrm{H}_{2} \mathrm{O}$.

\section{Phase Diagram}

Wyllie [1979] presented isoplethal diagrams for several values of $\mathrm{CO}_{2} / \mathrm{H}_{2} \mathrm{O}$. In particular, Figure 2 is a modified version of Wyllie's [1979] Figure $7 b$ for dolomite-amphibole-perido- tite, with additional limits for the stability of phlogopite based on estimates from Wyllie [1978, Figures 12 and 13]. Assuming that there is more $\mathrm{H}_{2} \mathrm{O}$ present than that required to make the maximum amount of phlogopite, then phlogopite cannot buffer the vapor phase. The lines separating phase fields with amphibole and phlogopite are narrow divariant bands, but their representation as lines does not affect the applications in this paper.

The vapor phase composition corresponds to the total $\mathrm{CO}_{2} /$ $\mathrm{H}_{2} \mathrm{O}$ in the system only in the two areas labeled $X_{\mathrm{co}}{ }^{V}=0.8$. In other areas the vapor composition is changed by the amounts of $\mathrm{CO}_{2}$ or $\mathrm{H}_{2} \mathrm{O}$ stored in carbonates or hydrous minerals. Where amphibole and dolomite coexist, there is no vapor phase remaining for the given ranges of $\mathrm{H}_{2} \mathrm{O}$ and $\mathrm{CO}_{2}$.

The vapor-buffered solidus $Q R$ is fixed whatever the ratio of $\mathrm{CO}_{2} / \mathrm{H}_{2} \mathrm{O}$ (part of the curve $Q_{2} R$ in Figures $1 b$ and $1 c$ ). The solidus $P M Q$ varies with this ratio, as do the boundaries limiting the fields for dolomite + phlogopite, phlogopite, and amphibole. These boundaries are contours corresponding to vapor phases of fixed compositions. With decreasing $X_{\mathrm{CO}_{2}}{ }^{V}$ the solidus contour migrates to lower temperatures, and the amphibole and phlogopite contours migrate to higher temperatures. The temperature maximum on the solidus, $M$, is a point on the dashed line $T_{\max }$ in Figures $1 a$ and $1 c$, which show how $M$ migrates to higher pressures and lower temperatures as $\mathrm{CO}_{2} / \mathrm{H}_{2} \mathrm{O}$ decreases.

The thermal barrier represented by the line $T_{\max }$ and illustrated by point $M$ is associated with marked changes in liquid and vapor compositions. At pressures below $M$ along the solidus $P M$ the liquid prefers $\mathrm{H}_{2} \mathrm{O}$, and the $\mathrm{CO}_{2}$ is preferentially displaced into the vapor phase. At pressures above $M$ above the solidus $M Q R$, the liquid prefers $\mathrm{CO}_{2}$, leaving $\mathrm{H}_{2} \mathrm{O}$ preferentially displaced into the vapor phase. This is manifest by the increasing $\mathrm{H}_{2} \mathrm{O} / \mathrm{CO}_{2}$ in the vapor along the buffered solidus $Q R$ (see Figure 1c). The liquid composition near the solidus $P M$ is affected mainly by $\mathrm{H}_{2} \mathrm{O}$, whereas the liquid along the solidus $M Q R$ is strongly depleted in $\mathrm{SiO}_{2}$ through the influence of $\mathrm{CO}_{2}$ [Eggler, 1974]. It is now generally agreed that carbonatitic and kimberlitic liquids are produced above the solidus $Q R$ for systems with a wide range of $\mathrm{CO}_{2} / \mathrm{H}_{2} \mathrm{O}$. The amount of such liquid produced at a given temperature depends mainly on the amount of $\mathrm{CO}_{2}$. 
The phase boundaries from Figure 2 have been transposed and reproduced in Figure 3 within a depth-temperature framework, with a geotherm representing temperatures within the mantle beneath the continental shields. The solidus for peridotite without volatile components is shown by a dashed line (Figure 1), and some other relevant reactions have been added. Dense hydrous magnesium silicates (DHMS) are possible deep storage sites for $\mathrm{H}_{2} \mathrm{O}$ in the mantle [Yamamoto and Akimoto, 1977; Ringwood, 1975].

The transition from spinel-peridotite to garnet-peridotite has been omitted in the present treatment in order to simplify the diagrams [see Wyllie, 1978, Figure 2; Wyllie, 1979, Figure 1].

The buffered solidus curve for phlogopite-dolomite-peridotite-Vb has been extrapolated well beyond the limits of available experimental data. There is also uncertainty about the fate of phlogopite, which certainly breaks down in the subsolidus assemblage at depths between about 150 and $250 \mathrm{~km}$.

\section{Petrological Cross-Section Through Static Mantle}

It is now possible to construct fairly accurate petrological cross sections for an upper mantle with any assumed geotherm, peridotite composition, and $\mathrm{CO}_{2}$ and $\mathrm{H}_{2} \mathrm{O}$ contents [Wyllie, 1979]. The mantle cross sections so derived are not stable, because migration of interstitial vapor or magma would redistribute $\mathrm{H}_{2} \mathrm{O}$ and $\mathrm{CO}_{2}$, as well as the incompatible elements that become concentrated into the magmas. However, they provide a starting point for examination of processes in a dynamic mantle.

Figure 4a, based on Figures 2 and 3, gives a shield geotherm and the relevant phase boundaries for a specific model of the upper mantle. The normal mantle peridotite is assumed to contain uniformly distributed $\mathrm{CO}_{2}$ and $\mathrm{H}_{2} \mathrm{O}$ in small amounts, less than the limits indicated in Figure 2, with ratio $\mathrm{CO}_{2} /\left(\mathrm{CO}_{2}+\mathrm{H}_{2} \mathrm{O}\right)=0.8$. At shallow depths in the absence of carbonates or hydrous minerals, all volatile components remain in a vapor phase with composition $X_{\mathrm{CO}_{2}}{ }^{v}=0.8$. The vapor phase composition changes according to the amounts of $\mathrm{CO}_{2}$ and $\mathrm{H}_{2} \mathrm{O}$ stored in carbonates or hydrous minerals, as discussed in connection with Figures 2 and 3. In particular, between $Q$ and $R$ on the solidus the subsolidus vapor phase is strongly enriched in $\mathrm{H}_{2} \mathrm{O}$ by the buffering capacity of dolomite.

Figure $4 b$ represents a cross section through the crust and mantle in a shield region for this specific mantle peridotite, which is obtained by tracing the shield geotherm of Figure $4 a$ through the phase fields and boundaries. The transition from spinel-peridotite to garnet-peridotite is omitted. Descending through the mantle below the crust, there is first a layer of dolomite-amphibole-peridotite, with no free vapor phase. At a depth of about $90 \mathrm{~km}$, amphibole is replaced by phlogopite and vapor. Along this geotherm the vapor phase has high $\mathrm{H}_{2} \mathrm{O} / \mathrm{CO}_{2}$, as can be determined by the vapor phase contours on the surfaces for the dissociation of dolomite-peridotite and dolomite-phlogopite-peridotite [see Wyllie, 1978, Figures 3a, $9 a, 15 a$, and $15 b]$. The shield geotherm crosses the solidus curve between depths of about $120 \mathrm{~km}$ and $260 \mathrm{~km}$, and within this interval there is a trace of magma. The components of carbonate, phlogopite, and vapor are dissolved in the melt. Below this region of partial melting, magnesite-peridotite exists with buffered vapor extremely rich in $\mathrm{H}_{2} \mathrm{O}$. Details of phase relationships for phlogopite-peridotite composi- tion at these pressures are not known, but the components of phlogopite must be distributed between the vapor and other minerals.

In the upper part of the partially melted zone the liquid composition would be carbonatitic, changing to more silicic, kimberlitic compositions with increasing depth. There are many different liquid composition paths through a wide temperature interval for the partial melting of phlogopite-dolomite-peridotite, and these vary as a function of pressure. Brey and Green $[1975,1976]$ confirmed that olivine-melilitite compositions are possible near-solidus liquids from peridotite$\mathrm{CO}_{2}-\mathrm{H}_{2} \mathrm{O}$ at high pressures. The possible occurrence of carbonatitic liquids near $120-\mathbf{k m}$ depth is consistent with the suggestion of Franz and Wyllie [1967] that such melts could be involved with the fluidized emplacement of some kimberlite magmas. The changing composition of interstitial magma as a function of depth is also consistent with the proposal of Boyd and Nixon [1973] that kimberlite magmas could be hybrid mixtures of silicate liquids from within the asthenosphere and carbonatite liquids from near the top of the asthenosphere.

The problem of the residence time of interstitial magma in the upper mantle was reviewed recently by Walker et al.

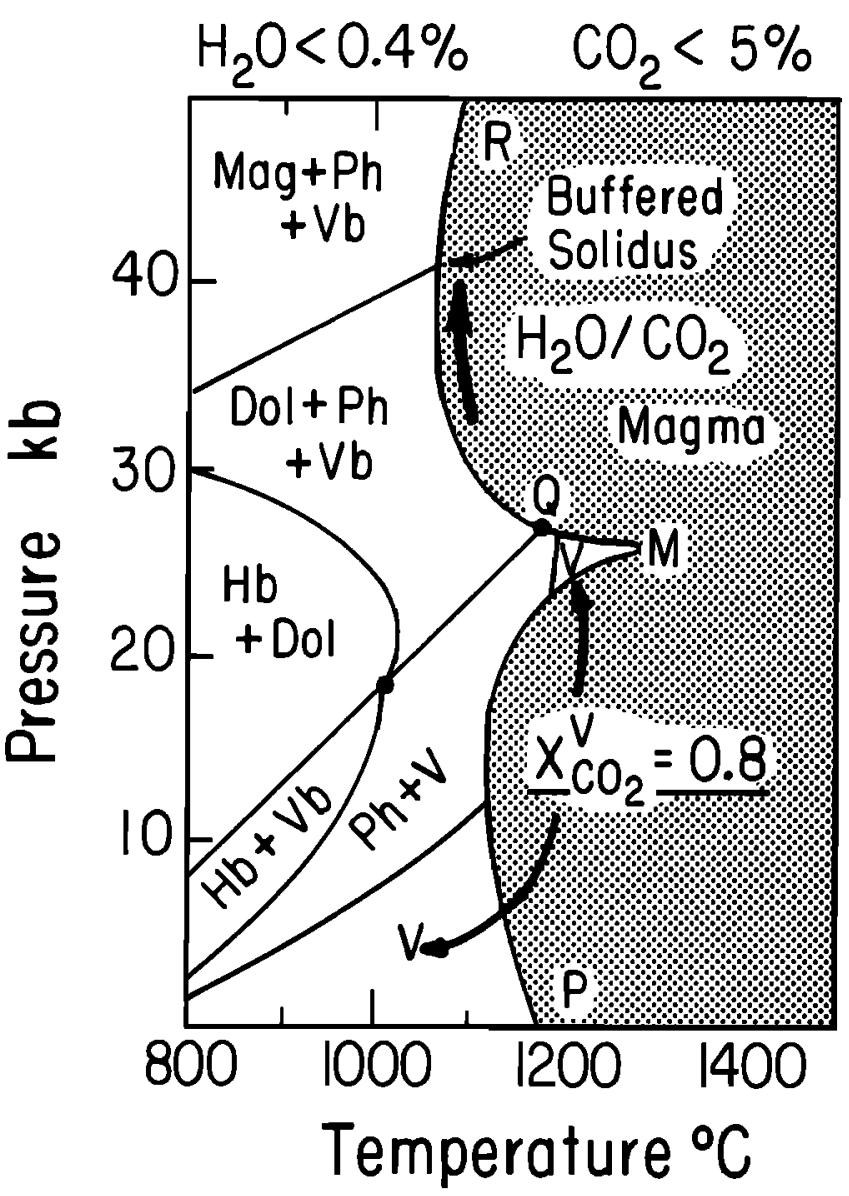

Fig. 2. Schematic phase diagram for peridotite with small amounts (by weight) of $\mathrm{CO}_{2}$ (less than $5 \%$ ), $\mathrm{H}_{2} \mathrm{O}$ (less than $0.4 \%$ and greater than $0.02 \%$ ), and $\mathrm{CO}_{2} /\left(\mathrm{H}_{2} \mathrm{O}+\mathrm{CO}_{2}\right)=0.8$ (mole ratio). The diagram is similar to that presented by Wyllie [1979, Figure $7 b]$. The solidus curve is given by the heavy line $P M Q R$. Along the line $Q R$ the vapor phase is greatly enriched in $\mathrm{H}_{2} \mathrm{O} / \mathrm{CO}_{2}$ with increasing pressure, as illustrated in Figure 1c. The composition of the liquids produced near the solidus along the line $Q R$ range from carbonatitic to kimberlitic, to various low-SiO $\mathrm{O}_{2}$, high-alkali, carbonated magmas. $\mathrm{Hb}$ is amphibole, and Mag is magnesite solid solution. 


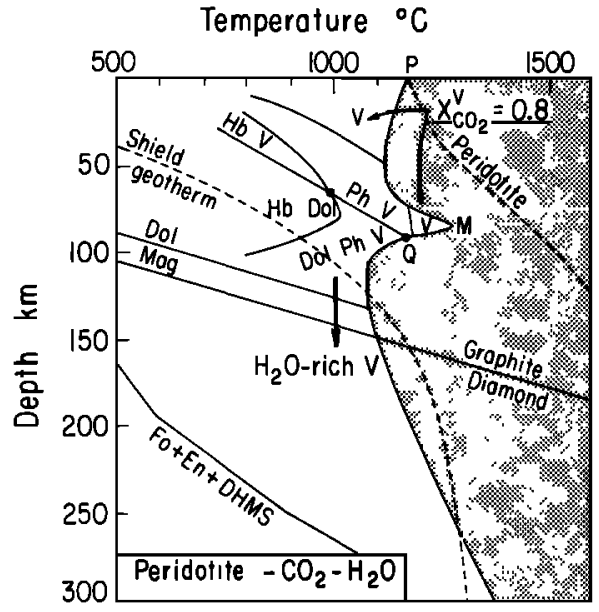

Fig. 3. The phase boundaries for peridotite $\mathrm{CO}_{2}-\mathrm{H}_{2} \mathrm{O}$ from Figure 2 transposed to a depth-temperature diagram, with the addition of other relevant phase boundaries, and comparison of an estimated shield geotherm. The vapor-absent peridotite solidus is shown for comparison. Fo is forsterite, En is enstatite, and DHMS is dense hydrous magnesian silicates.

[1978]. The amount of melt required to explain the seismic properties of the low-velocity zone depends in uncertain fashion on the geometrical distribution of interstitial magma, in blebs, tubules, ribbons, or surface channels. The same factors influence the amount of melt that can remain mechanically stable in mantle peridotite. Walker et al. [1978] suggested that the seismically inferred melt fraction in the low-velocity zone could be understood as a drainage residue. They calculated that melt fractions greater than the range $0.1-1 \%$ would drain upward rapidly.

According to Figure $4 b$, dolomite should be distributed through the upper mantle wherever $\mathrm{CO}_{2}$ is present, but there appears to be only a single reported occurrence of dolomite in peridotite nodules [McGetchin and Besancon, 1973]. If we assume that values of about $0.2 \% \mathrm{CO}_{2}$ in oceanic basalts represent a fivefold concentration, then the mantle peridotite would have contained about $0.04 \% \mathrm{CO}_{2}$. This amount of $\mathrm{CO}_{2}$ would produce about $0.1 \%$ modal dolomite, which would not be obvious in a hand specimen or even under the microscope. Wyllie and Huang [1976] estimated that it would require about $0.5 \%$ dolomite $\left(0.25 \% \mathrm{CO}_{2}\right)$ to produce about $1 \%$ melt at the solidus.

An approach followed by experimental petrologists to explain the origin of magmas is to seek the mantle material that could yield the required liquid composition if the temperature rises above the solidus. Phlogopite-dolomite-peridotite is a suitable source, capable of yielding kimberlitelike magmas. However, according to Figure 4 this source rock can exist only at levels shallower than about $120 \mathrm{~km}$ beneath continental shields, because it would be partially melted at greater depths. Therefore the kimberlites that commonly transport mantle nodules from depths greater than $150 \mathrm{~km}$ [e.g., Boyd, 1973] could not have been derived by the partial melting of phlogopite-dolomite-peridotite. Yet the components of phlogopite and dolomite must have been involved in the kimberlite generation from peridotite.

One possibility is that $\mathrm{CO}_{2}, \mathrm{H}_{2} \mathrm{O}$, and phlogopite components are present in a persistent partially melted zone such as that represented in Figure $4 b$ and that the kimberlites and compositionally related magmas are derived from this layer from time to time. However, the fact that the seismic low-velocity zone beneath continental shields is weakly developed or absent [Solomon, 1976] suggests that mantle peridotite in these regions contains little or no interstitial melt and therefore little or no $\mathrm{CO}_{2}$ and $\mathrm{H}_{2} \mathrm{O}$. A second possibility is that $\mathrm{H}_{2} \mathrm{O}$ and $\mathrm{CO}_{2}$ are sparsely and irregularly distributed through the subcontinental mantle, dissolved in local melt concentrations at depth between 120 and $260 \mathrm{~km}$, with periodic magmatic flushes transporting the magma into the overlying lithosphere or through it if tectonic conditions are suitable. A third possibility is that the components $\mathrm{C}-\mathrm{H}-\mathrm{O}$ may occur in the mantle peridotite without the occurrence of melting if reduced oxygen fugacity raises the solidus for the system peridotite-C-H$O$, especially if the subcontinental geotherm is lower than that plotted. Partial melting would then occur only where temperatures were raised or oxygen fugacity was increased.

None of these possibilities is very satisfactory for a dynamic mantle. The basic petrological problem is the question of whence and how the components of phlogopite and dolomite are introduced into mantle peridotite at depths of $150 \mathrm{~km}$ or more. If they had not been long-term residents of the upper mantle, stored as reduced subsolidus components or dissolved in interstitial melt $(0.1-1 \%)$ awaiting the necessary tectonic impulse for eruption to occur, then they must have been introduced from above (unlikely for cratonic environment), by lateral migration (unlikely at this level), or from below. It is time-honored practice for petrologists to push the ultimate origins of magmas to depths greater than the limits of their experimental knowledge, and it may be that the source of volatile components responsible for the generation of kimberlites and other subsilicic magmas is deeper [Ernst and Schwab, 1972; Perchuk, 1977]. There is a good prospect that carbon from subducted limestones could be carried down for longterm storage in the deeper mantle [Huang et al., 1980], and this is one possible source of volatile components. The dense hydrous magnesian silicates (DHMS in Figure 3) represent another possible source.

\section{PALEOGEOTHERMS AND DIAPIRS}

Applications of geothermometry and geobarometry to the mantle peridotite nodules transported through the crust by

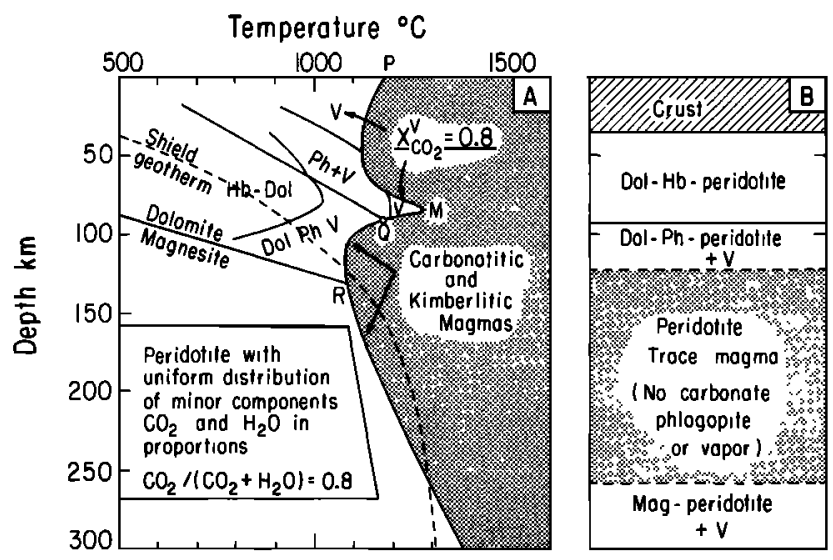

Fig. 4. The petrology of a mantle cross section for peridotite assuming uniform distribution of minor components $\mathrm{CO}_{2}$ and $\mathrm{H}_{2} \mathrm{O}$ in the proportions $\mathrm{CO}_{2} /\left(\mathrm{CO}_{2}+\mathrm{H}_{2} \mathrm{O}\right)=0.8$ and assuming a shield geotherm. A trace of interstitial magma occurs within the depth interval about $120 \mathrm{~km}$ to about $260 \mathrm{~km}$, incorporating the components of phlogopite, dolomite, and vapor. 


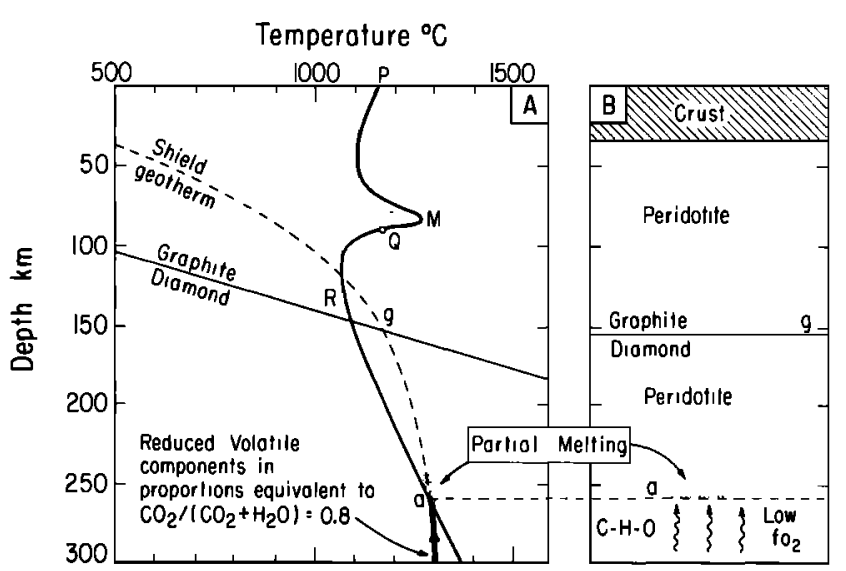

Fig. 5. Mantle cross section for peridotite containing neither $\mathrm{CO}_{2}$ nor $\mathrm{H}_{2} \mathrm{O}$, with traces of carbon occurring as graphite or diamond above and below level $g$. In the absence of volatile components the solidus curve $P M Q R$ extrapolated to $300 \mathrm{~km}$ has no significance. Volatile components released from greater depths would rise upward along the geotherm, cross the solidus at level $a$, and cause partial melting.

kimberlites delineate paleogeotherms similar to that given in Figure 4, but with inflections occurring at depths between 140 and $200 \mathrm{~km}$, where the curves steepen abruptly to higher temperatures [Boyd, 1973]. The paleogeotherms, which correspond to the dates of emplacement of specific kimberlites, are inconsistent with steady state thermal models. Boyd [1973] suggested initially that they could represent shear heating in the asthenosphere during the breakup of Gondwanaland. Green and Gueguen [1974] suggested that they represent thermal perturbations caused by diapiric upwelling from within or below the asthenosphere.

Green and Gueguen [1974] postulated the development of a small density inversion of unknown origin at a depth of more than $200 \mathrm{~km}$, which initiated upwelling of solid peridotite. They calculated times and velocities and related chemical and textural differences between nodules from different depths to their model in satisfactory fashion. They assumed that partial melting occurred at temperatures just above the hottest temperatures indicated on the steeper portion of the paleogeotherms, and this made small amounts of $\mathrm{H}_{2} \mathrm{O}$ mandatory for the model. Kimberlite pipes escaped from the top of the diapir.
The solidus for peridotite-vapor with $\mathrm{H}_{2} \mathrm{O} / \mathrm{CO}_{2}=\frac{1}{3}$ [Mysen and Boettcher, 1975] was used in their interpretation. Despite the high ratio of $\mathrm{CO}_{2} / \mathrm{H}_{2} \mathrm{O}$ adopted, the influence of $\mathrm{CO}_{2}$ was not discussed further. Green [1972] and Green and Radcliffe [1975] described $\mathrm{CO}_{2}$ inclusions in the minerals of mantle nodules and suggested that $\mathrm{CO}_{2}$ might be the fluid responsible for the seismic low-velocity zone. This proposal is now known to be untenable, because $\mathrm{CO}_{2}$ reacts with peridotite to produce dolomite (Figures 2, 3, and 4).

\section{MODIFIED DIAPIRIC MODEL FOR THE ORIGIN OF KIMBERLITES}

The high-pressure solidus for peridotite- $\mathrm{CO}_{2}-\mathrm{H}_{2} \mathrm{O}$ has a shape very different from that assumed by Green and Gueguen [1974], and the phase diagram for phlogopite-dolomite-peridotite given in Figure 2 can now be used as the basis for a modified diapiric interpretation for the origin of kimberlites.

\section{Solidus for Peridotite- $\mathrm{C}-\mathrm{H}-\mathrm{O}$}

Although the evidence is clear for the existence of components $\mathrm{CO}_{2}$ and $\mathrm{H}_{2} \mathrm{O}$ in magmas reaching the crust, and although the involvement of carbonate and $\mathrm{CO}_{2}$ appears to be required for generation of magmas of kimberlite composition, the fact that kimberlites and their xenoliths contain diamond and graphite confirms that the oxygen fugacity at depth is not high enough to oxidize all carbon. There is probably a depth interval within which carbon and carbonate can coexist (M. Sato, personal communication, 1977; see also Rosenhaur et al. [1977] and Woermann et al. [1977]).

From the relatively low intrinsic oxygen fugacity in rocks and magmas derived from the mantle, Eggler et al. [1979] concluded that vapors in the mantle should contain both $C O$ and $\mathrm{CO}_{2}$ as well as some $\mathrm{H}_{2} \mathrm{O}$ and perhaps $\mathrm{CH}_{4}$. They measured the solubility of $\mathrm{CO}-\mathrm{CO}_{2}$ vapors in equilibrium with graphite in several silicate melts at pressures to 30 kbar and temperatures to $1700^{\circ} \mathrm{C}$ and concluded that $\mathrm{CO}$ has about the same effect on peridotite phase relations as does $\mathrm{CO}_{2}$. Preliminary experiments by D. H. Eggler (personal communication, 1979) indicate that $\mathrm{CH}_{4}$ lowers the melting temperature of diopside so much that this component must also have a large effect on peridotite melting.

In the absence of other data, assume that the solidus curve in Figure 4 applies to peridotite together with the components

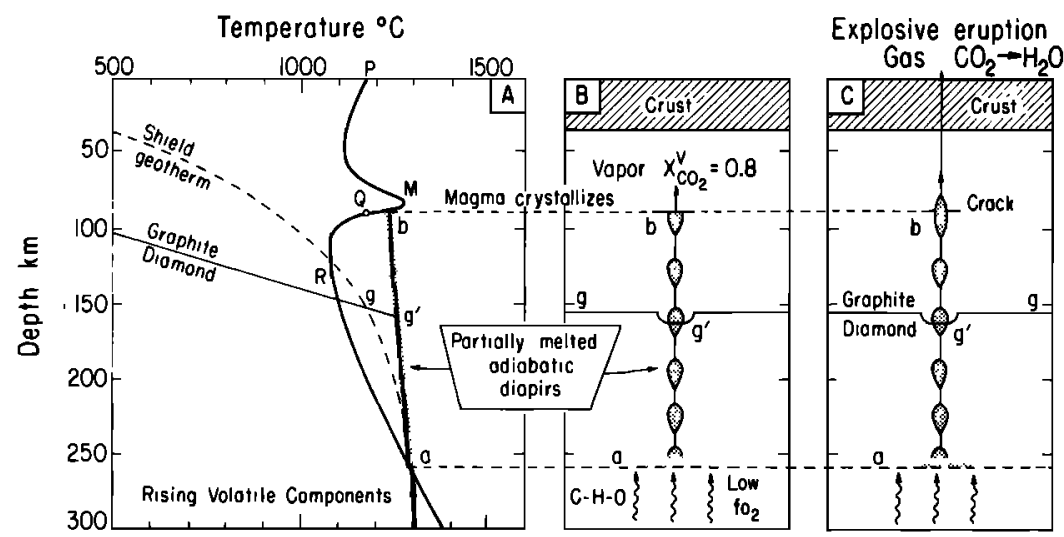

Fig. 6. A diapiric model for the origin and eruption of kimberlitic magmas, triggered by volatile components rising from deep within the earth. The partial melting initiated in Figure 5 produces a density inversion, which is followed by the uprise of partially melted adiabatic diapirs along the path $a$ to $b$. At level $b$ the magma crystallizes. Crystallization is accompanied by evolution of $\mathrm{CO}_{2}$-rich vapor, which may initiate crack propagation through the overlying lithosphere, followed by explosive eruption of the magma rising from a depth of about $90 \mathrm{~km}$. 


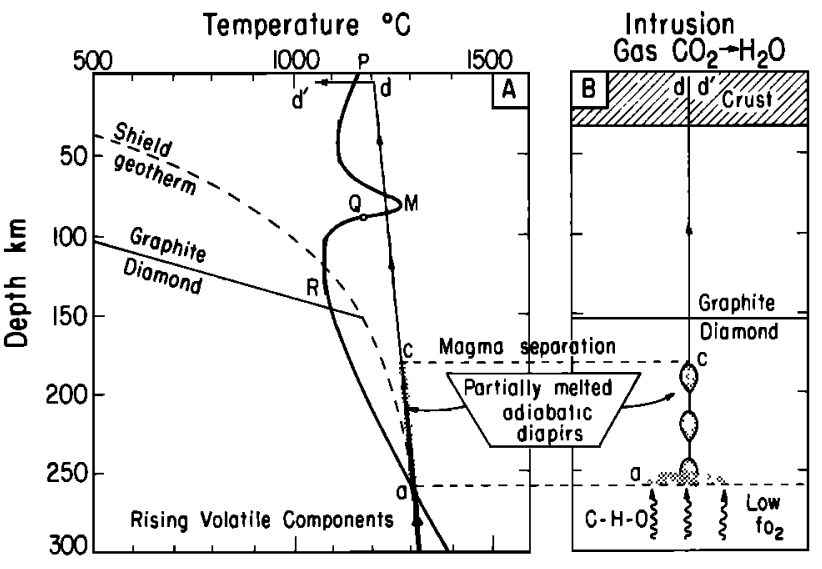

Fig. 7. A mechanism for the origin and emplacement of kimberlite magmas bearing diamonds. If a conduit to the surface has been established by crack propagation as illustrated in Figure 6, then magma separation may occur from partially melted adiabatic diapirs at progressively deeper levels, extending down through a region which may contain diamonds.

$\mathrm{C}-\mathrm{H}-\mathrm{O}$ in proportions so that they are equivalent to $\mathrm{CO}_{2}$ / $\left(\mathrm{CO}_{2}+\mathrm{H}_{2} \mathrm{O}\right)=0.8$, whatever the oxygen fugacity may be. The position of the buffered solidus $Q R$ does not change for a very wide range of $\mathrm{CO}_{2} / \mathrm{H}_{2} \mathrm{O}$ in peridotite (see Figure 1), so that this deeper portion of the solidus can be applied to most compositions. The presence of other volatile components might cause increase or decrease in temperature of the solidus curve. It is not known what these volatile components are or what their effect would be, but because the dominant components are likely to be $\mathrm{C}-\mathrm{H}-\mathrm{O}$, let us adopt the solidus curve from Figure 4 and use it as the limit in Figure $5 a$ for potential melting.

\section{Leakage of Volatile Components, Partial Melting, and Diapiric Uprise}

Consider mantle peridotite with no volatile components. For the shield geotherm given in Figure $5 a$ the petrological structure of the upper mantle is that shown in Figure $5 b$. The only phase boundary represented is given by the intersection at point $g$ of the geotherm with the graphite-diamond phase transition. Diamonds can only be carried to the surface by material rising from a depth of greater than $150 \mathrm{~km}$. The line $P M Q R$ extrapolated to greater depth in Figure $5 a$ shows where melting would begin in this peridotite composition in the presence of volatile components $\mathrm{C}-\mathrm{H}-\mathrm{O}$ in the stipulated proportions.

Assume that an unknown mechanism triggers the release of volatile components from the deep mantle and that the components $\mathrm{C}-\mathrm{H}-\mathrm{O}$ with low oxygen fugacity rise up the geotherm. When they reach level $a$ in Figure $5 a$, they would induce partial melting within the peridotite as they cross the solidus.

The upward migration of these volatile components and the development of a narrow zone of partial melting are represented in the petrological cross section of Figure $5 b$. This partial melting begins at a depth of about $260 \mathrm{~km}$, well within the stability field of diamond.

\section{Diapiric Uprise and Crack Propagation}

In the model of Green and Gueguen [1974] a density inversion occurs in solid mantle for unknown reasons, and a solid diapir rises to a higher level, where melting begins. In this modified model the density inversion is caused by partial melting induced by the upward migration of volatile components.

The adiabatic path of rising, partially melted diapirs is represented by $a b$ in Figures $6 a$ and $6 b$. Continued flow of volatile components could produce a series of successive diapirs. Within each diapir the percentage of liquid increases during uprise. The higher temperature of the diapirs compared with surrounding mantle depresses the diamond stability boundary from $g$ to $g^{\prime}$.

Figure $6 a$ is designed to illustrate what would happen if a partially melted diapir reaches the solidus for peridotite-vapor at point $b$ between $Q$ and $M$ on the temperature maximum (thermal barrier). The detailed phase relationships are given in Figures 2, 3, and 4a. At this level, if equilibrium is maintained, the magma will evolve vapor with composition $X_{\mathrm{CO}_{2}}{ }^{V}$ $=0.8$ (assuming that the oxygen fugacity is high enough), and the magma will crystallize completely. The hot, solidified diapir may continue to rise, and melting could begin again as the diapir crossed the solidus $M P$ if the volatile components were retained. The liquid associated with the solidus $M P$ differs markedly from the carbonatitic and kimberlitic liquids associated with the solidus $Q R$ [Wyllie, 1979, Figure 8].

Anderson [1979] considered the fracture mechanics of how kimberlite magma could be transported rapidly from great depths. He concluded that an abundant supply of low-viscosity fluid was necessary to allow a crack to accelerate and reach the surface. The evolution of vapor at level $b$ in Figure 6 could thus enhance the prospects for crack propagation if tectonic conditions were suitable, with the lithosphere in a state of tension. If cracks developed and propagated, this could be followed by explosive eruption of vesiculating, partially crystallized magma directly from a depth of about $90 \mathrm{~km}$ (Figure $6 c)$. At and near the surface the vapor phase composition would change from $\mathrm{CO}_{2}$ rich to $\mathrm{H}_{2} \mathrm{O}$ rich with continued cooling and crystallization.

\section{Emplacement of Kimberlite With Diamonds}

Magmas erupted from level $b$ in Figure 6 would not bear diamonds, nor would they transport mantle nodules representing paleogeotherms deeper than $100 \mathrm{~km}$. However, once a conduit to the surface has been established by explosive eruption from the solidus barrier at about $90-\mathrm{km}$ depth, magma separation could occur from successive diapirs at greater depths, as illustrated schematically in Figure 7. These magmas would pass through the diamond stability field.

Magmas escaping from deeper levels, such as $c$ in Figure 7, would be undersaturated in $\mathrm{CO}_{2}$ and $\mathrm{H}_{2} \mathrm{O}$, and the magma could rise to near-surface levels quite unaffected by the thermal barrier $Q M$. The magmas from deeper sources could be erupted through the lithosphere as illustrated in Figure $6 c$, or they could be intruded to a level in the crust where they are trapped as illustrated by $d$ in Figure 7 . Only after uprise to low-pressure conditions would cooling and crystallization yield vapors changing from $\mathrm{CO}_{2}$ rich to $\mathrm{H}_{2} \mathrm{O}$ rich (e.g., path $d d^{\prime}$ in Figure 7a).

In a review lecture presented at a conference organized by De Beers (Kimberlite Symposium II, Cambridge, England, 1979), C. R. Clement synthesized the field evidence from many pipes. Most major kimberlite pipes reflect multiple intrusive events involving similar processes. Each event begins with the formation of an embryonic pipe by magma already differentiated, with a precursor gas phase involved in the de- 


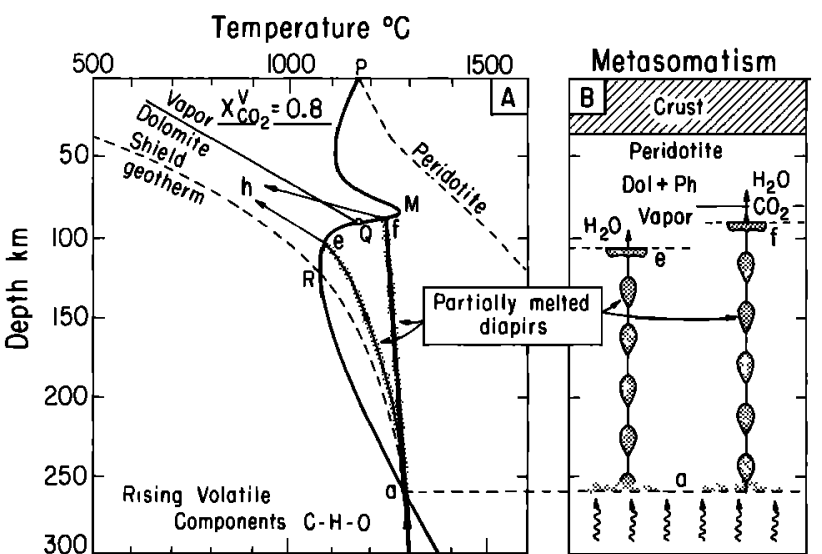

Fig. 8. Metasomatism of the upper mantle caused by fluids released from crystallizing pools of magma that did not escape by explosive eruption as in Figures 6 and 7. The adiabatic path of corresponds to the path $a b$ in Figure 6. In this example the magma cools at a level corresponding to the solidus, and $\mathrm{CO}_{2}$-rich gases migrate into the overlying lithosphere, cooling along a path such as $f h$, with precipitation of dolomite and increase in $\mathrm{H}_{2} \mathrm{O} / \mathrm{CO}_{2}$. Another path, ae, leads to crystallization of phlogopite and dolomite at $e$ and evolution of $\mathrm{H}_{2} \mathrm{O}$ rich vapor. In addition to $\mathrm{CO}_{2}$ and $\mathrm{H}_{2} \mathrm{O}$ derived originally from the deep volatile components $\mathrm{C}-\mathrm{H}-\mathrm{O}$, these solutions would contain high concentrations of incompatible elements. The solutions released by the deep-seated crystallization of kimberlitic and related magmas near the base of the lithosphere are likely candidates for the metasomatic solutions that have modified many mantle nodule samples.

velopment of a root zone. Explosive breaching of the surface from shallow depths forms the crater zone, associated with rapid depressurization, brecciation, an upsurge of magma from below the gas phase, and a short-duration fluidization event which evolves down the root zone, generating a diatreme zone involving the basal crater zone and the upper root zone. Clement described the root zone as being complex and irregular and being occupied by up to 20 separate intrusions of magmatic kimberlite. The major kimberlite pipes are derived not from a single explosive event within the upper mantle but either from some continuous or repetitive process occurring within the mantle or from a deep-seated magmatic chamber that is repeatedly tapped.

Following an initial explosive eruption from about $90-\mathrm{km}$ depth (see $b$ in Figure $6 a$ ), which established a conduit to the surface, multiple intrusions of kimberlite magma into a single pipe could be accomplished by magma separation from successive diapirs produced by continued leakage of volatile components or from a sequence of diapirs tapped at progressively deeper levels. It would be a useful exercise to see whether there is any progression in the deepest paleodepths for nodules recovered from successive intrusions into a single kimberlite pipe.

An alternative mechanism for multiple intrusions into a singel pipe requires the occurrence of deep-seated kimberlite magma chambers. Episodic buildup of vapor pressure could be associated with intermittent crack propagation and magma release along the preexisting, weakened conduits. This mechanism is consistent with Clement's conclusion that the kimberlite magma forming an embryonic pipe is already differentiated. Figure 8 includes a diagrammatic representation of kimberlite magma ponding into chambers near the base of the lithosphere, as the magma reaches the solidus $R Q M$ for peridotite- $\mathrm{CO}_{2}-\mathrm{H}_{2} \mathrm{O}$.

\section{Mantle Metasomatism}

There is now abundant evidence that some regions of the upper mantle have been subjected to metasomatism by fluids and enriched in incompatible elements. Boettcher et al. [1979] reviewed the evidence and concluded that the pervasive metasomatism was accomplished by aqueous fluids rich in $\mathrm{CO}_{2}$, $\mathrm{Ti}, \mathrm{Fe}, \mathrm{K}$, and other elements. Boettcher and $\mathrm{O}^{\prime} \mathrm{Neil}$ [1980] expanded the discussion of precursory metasomatic fluids to both silicate-rich melts and aqueous solutions. They concluded that metasomatism of mantle lherzolite is precursory to or concomitant with anatexis in the production of many deep-seated alkali basaltic magmas and kimberlites, and they referred to migrating fluids associated with mantle diapirism or plumes.

Knowledge of the buffered solidus for peridotite- $\mathrm{CO}_{2}-\mathrm{H}_{2} \mathrm{O}$ (Figure 2) places some possible limits on the extent of mantle metasomatism. According to Figure 4, aqueous fluids cannot exist at depths greater than about $120 \mathrm{~km}$ beneath continental shields (shallower in other tectonic environments with warmer geotherms). At greater depths the components $\mathrm{H}_{2} \mathrm{O}$ and $\mathrm{CO}_{2}$ would be dissolved in inerstitial magma. Mantle peridotite would certainly be modified by the migration of such magmas, but contamination and alteration by aqueous fluids is the process more commonly defined as metasomatism. Metasomatism could also occur at depths below about $260 \mathrm{~km}$, or at whatever depth the geotherm actually crosses the solidus for the system peridotite-volatile components (with appropriate oxygen fugacity), and it is this metasomatic change in bulk composition that causes melting at level $a$.

The dynamic processes for the stipulated geotherm and phase diagram are illustrated schematically in Figure 8 . The volatile components rising from unknown depths could cause metasomatism until they reached the level where magma generation is initiated, represented in Figure 8 by $a$, near $260 \mathrm{~km}$. Consider first the path af, which represents the adiabatic uprise of partially melted diapirs as developed for path $a b$ in Figure 6. In this example, crystallization and evolution of $\mathrm{CO}_{2}-$ rich gases at point $f$ is not accompanied by cracking and explosive eruption. Instead, it is assumed that diapiric uprise is slowed or halted by the increasing rigidity of the lower lithosphere and that the interstitial magma, halted by vesiculation and crystallization, collects into chambers near level $f$, corresponding to the solidus boundary. The escaping vapors passing through the overlying mantle may cool along a path such as $f h$ in Figure $8 a$, reacting with the mantle to produce phlogopite, dolomite, amphibole, and possibly other metasomatic minerals. The details depend upon the position of the cooling path with respect to the phase fields given in Figure 3. Some of the phase boundaries vary as a function of $\mathrm{CO}_{2} / \mathrm{H}_{2} \mathrm{O}$ in the system [Wyllie, 1978, 1979]. If the cooling path crosses the dolomite phase boundary, the high-temperature $\mathrm{CO}_{2}$-rich fluids become rapidly enriched in $\mathrm{H}_{2} \mathrm{O}$.

Consider now a situation where the partially melted diapirs exchange heat with the surrounding mantle, following a cooler path such as ae, or where the magma generated at level a simply drains upward along a similar depth-temperature path [cf. Walker et al., 1978]. Collection of the magma into pools at depth $e$ is accompanied by precipitation of dolomite, phlogopite, and other silicate minerals. For small amounts of total volatile components passing through level $a$, crystallization could be completed at $e$ with all $\mathrm{H}_{2} \mathrm{O}$ and $\mathrm{CO}_{2}$ stored in phlogopite and dolomite. However, any excess of volatile 
components would cause evolution of an aqueous vapor (Figure $1 c$ ) which could migrate into the overlying mantle along a path such as $e h$, producing metasomatism with the precipitation of phlogopite, dolomite, amphibole, and other minerals (compare $e h$ in Figure $8 a$ with the phase boundaries in Figure 3).

Consider the metasomatized mantle generated at levels above $e$ and $f$ in Figure $8 b$, and compare the solidus curve with the continental geotherm in Figure $8 a$. The metasomatized mantle is certainly a potential source for the generation of exotic magmas, but it would require a rather significant thermal perturbation to raise the temperature above the solidus in the depth interval above ef.

If one accepts a single postulate, that volatile components stored in the deep mantle can escape and leak upward, then according to the conditions stipulated in Figure 8, there is a region of deep-seated metasomatism, followed upward by a zone of partial melting, followed in turn by metasomatism of the upper mantle by hydrothermal fluids. Metasomatism of the upper mantle at shallower levels is then a consequence and not necessarily a cause of magma generation. This hydrothermal metasomatism cannot be a precursor of kimberlite magma genesis for those kimberlites bearing diamonds or peridotite nodules with paleodepths greater than about $120 \mathrm{~km}$, because if the components of the hypothetical fluids exist in these source regions, then they would exist as components dissolved in magmas.

\section{Generation of CONTINENTAL Basalts}

A minor thermal perturbation might be sufficient to trigger the release of volatile components and the generation of kimberlite or related magmas, whereas a major thermal perturbation would be required to generate basalt from mantle diapirs in subcratonic mantle. The existence of locally metasomatized or enriched upper mantle could affect the geochemistry of the basalts erupted.

For the generation of normal basaltic magmas in continental regions the peridotite must be transported above the dashed line for the peridotite solidus in Figure $8 a$. For generally accepted geotherms in shield environments this requires convective or diapiric upwelling from depths considerably greater than the displacements required for generation of kimberlitic magmas, according to the schemes outlined in Figures 6-8.

The adiabatic uprise of deep-seated mantle to a level where it crosses the peridotite solidus would generate tholeiitic basaltic magmas with geochemical signatures corresponding to the deep source material. If the upwelling material traversed a portion of the upper mantle that had been metasomatized and enriched in incompatible elements, however, the thermal disturbance could be sufficiently great that melting could be induced in this resident mantle.

Partial melting of metasomatized mantle heated above the solidus $\operatorname{ReQfM}$ caused by the passage of uprising, hotter mantle could produce magmas with compositions ranging from olivine melilitites to carbonatites. Heating of metasomatized mantle at shallower depths would release volatile components by dissociation reactions, and partial melting above the solidus $M P$ (or other contours on the peridotite- $\mathrm{CO}_{2}-\mathrm{H}_{2} \mathrm{O}$ solidus [Wyllie, 1978, Figures 4 and 7]) could produce alkali basalts [Wyllie, 1979, Figure 8]. The amount of magma produced in this way would be small in comparison with that of tholeiitic basalt. There is a possibility that tholeiitic basalt generated from the deep-seated mantle source could be contaminated by magmas generated from metasomatized upper mantle material. The interpretation of isotope and trace element geochemistry for continental basalts may be more complex than some of the simple models currently in vogue.

\section{CONCLUDING REMARKS}

A final note of caution is needed, because the processes described are based on the selection of a particular geotherm, and a particular interpretation for the phase diagram of peridotite with selected amounts of $\mathrm{CO}_{2}$ and $\mathrm{H}_{2} \mathrm{O}$, and because the consequences of reduced oxygen fugacity at depth have not been adequately determined. If the solidus curve does not intersect the geotherm, these processes cannot occur, and kimberlite magma genesis then has to be associated with significant thermal perturbations of subcontinental mantle.

Acknowledgments. This research was supported by the Earth Sciences Section, National Science Foundation, grant EAR 76-20410. I also thank Barry Hawthorne for an invitation to Kimberlite Symposium II, where many aspects of this paper first gelled.

\section{REFERENCES}

Anderson, A. T., Some basaltic and andesitic gases, Rev. Geophys. Space Phys., 13, 37-55, 1975.

Anderson, $\mathbf{O}$. L., The role of fracture dynamics in kimberlite pipe formation, in Kimberlites, Diatremes, and Diamonds: Their Geology, Petrology, and Geochemistry, edited by F. R. Boyd and H. O. A. Meyer, pp. 344-353, AGU, Washington, D. C., 1979.

Boettcher, A. L., and J. R. O'Neil, Stable isotope, chemical, and petrographic studies of high-pressure amphiboles and micas: Evidence for metasomatism in the mantle source regions of alkali basalts and kimberlites, Amer. J. Sci., in press, 1980.

Boettcher, A. L., J. R. O'Neil, K. E. Windom, D. C. Stewart, and H. G. Wilshire, Metasomatism of the upper mantle and the genesis of kimberlites and alkali basalts, in The Mantle Sample: Inclusions in Kimberlites and other Volcanics, edited by F. R. Boyd and H. O. A. Meyer, pp. 173-182, AGU, Washington, D. C., 1979.

Boyd, F. R., A pyroxene geotherm, Geochim. Cosmochim. Acta, 37, 2533-2546, 1973.

Boyd, F. R., and P. H. Nixon, Origin of the ilmenite-silicate nodules in kimberlites from Lesotho and South Africa, Lesotho Kimberlites, edited by P. H. Nixon, pp. 254-268, Maseru Lesotho National Development Corporation, Lesotho, 1973.

Brey, G., and D. H. Green, The role of $\mathrm{CO}_{2}$ in the genesis of olivine melilitite, Contrib. Mineral. Petrol., 49, 93-103, 1975.

Brey, G., and D. H. Green, Solubility of $\mathrm{CO}_{2}$ in olivine melilitite at high pressure and role of $\mathrm{CO}_{2}$ in the earth's upper mantle, Contrib. Mineral. Petrol., 55, 217-230, 1976.

Eggler, D. H., Effect of $\mathrm{CO}_{2}$ on the melting of peridotite, Carnegie Inst. Wash. Yearb., 73, 215-224, 1974.

Eggler, $\mathrm{D}$. H., The principle of the zone of invariant vapor composition: An example in the system $\mathrm{CaO}-\mathrm{MgO}-\mathrm{SiO}_{2}-\mathrm{CO}_{2}-\mathrm{H}_{2} \mathrm{O}$ and implications for the mantle solidus, Carnegie Inst. Wash. Yearb., 76, 428-435, 1977.

Eggler, D. $\mathrm{H}$., The effect of $\mathrm{CO}_{2}$ upon partial melting of peridotite in the system $\mathrm{Na}_{2} \mathrm{O}-\mathrm{CaO}-\mathrm{Al}_{2} \mathrm{O}_{3}-\mathrm{MgO}-\mathrm{SiO}_{2}-\mathrm{CO}_{2}$ to $35 \mathrm{~kb}$, with an analysis of melting in a peridotite- $\mathrm{H}_{2} \mathrm{O}-\mathrm{CO}_{2}$ system, Amer. J. Sci., 278, 305-343, 1978.

Eggler, D. H., and R. F. Wendlandt, Experimental studies on the relationship between kimberlite magmas and partial melting of peridotite, in Kimberlites, Diatremes, and Diamonds: Their Geology, Petrology, and Geochemistry edited by F. R. Boyd, and H. O. A. Meyer, pp. 330-338, AGU, Washington, D. C., 1979.

Eggler, D. H., B. O. Mysen, T. C. Hoering, and J. R. Holloway, The solubility of carbon monoxide in silicate melts at high pressures and its effect on silicate phase relations, Earth Planet. Sci. Lett., 43, 321-330, 1979.

Ellis, D. E., and P. J. Wyllie, Phase relations in the system $\mathrm{MgO}^{-S_{i O}}{ }_{2}$ $\mathrm{H}_{2} \mathrm{O}-\mathrm{CO}_{2}$ at pressures up to $100 \mathrm{kbar}$ and petrological implications, Amer. Mineral., 65, in press, 1980.

Ernst, Th., and R. Schwab, A new theory on the formation and ascent 
of basic magmas with special respect to the undersaturated series, paper presented at the 24th Session, International Geological Congress, Section 14, Mineralogy, Montreal, 1972.

Franz, G. W., and P. J. Wyllie, Experimental studies in the system $\mathrm{CaO}-\mathrm{MgO}-\mathrm{SiO}_{2}-\mathrm{CO}_{2}-\mathrm{H}_{2} \mathrm{O}$, in Ultramafic and Related Rocks, edited by P. J. Wyllie, pp. 323-326, John Wiley, New York, 1967.

Green, H. W., II, A CO $\mathrm{CO}_{2}$ charged asthenosphere, Nature Phys. Sci, $238,2-5,1972$.

Green, H. W., II, and Y. Gueguen, Origin of kimberlite pipes by diapiric upwelling in the upper mantle, Nature Phys. Sci., 249, $617-$ $620,1974$.

Green, H. W., and S. V. Radcliffe, Fluid precipitates in rocks from the earth's mantle, Geol. Soc. Amer. Bull., 86, 846-852, 1975.

Holloway, J. R., and D. H. Eggler, Fluid-absent melting of peridotite containing phlogopite and dolomite, Camegie Inst. Wash. Yearb., $75,636-639,1976$.

Huang, W. L., P. J. Wyllie, and C. E. Nehru, Subsolidus and liquidus phase relationships in the system $\mathrm{CaO}-\mathrm{SiO}_{2}-\mathrm{CO}_{2}$ to $30 \mathrm{kbar}$ with geological applications, Amer. Mineral., 65, in press, 1980.

Irving, A. J., and P. J. Wyllie, Melting relationships in $\mathrm{CaO}-\mathrm{CO}_{2}$ and $\mathrm{MgO}-\mathrm{CO}_{2}$ to 36 kilobars, with comments on $\mathrm{CO}_{2}$ in the mantle, Earth Planet. Sci. Lett., 20, 220-225, 1973.

Kennedy, G. C., and B. E. Nordlie, The genesis of diamond deposits, Econ. Geol., 63, 495-503, 1968.

Kerrick, D. M., Review of metamorphic mixed volatile $\left(\mathrm{H}_{2} \mathrm{O}-\mathrm{CO}_{2}\right)$ equilibria, Amer. Mineral., 59, 729-762, 1974.

McGetchin, T. R., and J. R. Besancon, Carbonate inclusions in mantle-derived pyrope, Earth Planet. Sci. Lett., 18, 408-410, 1973.

Mysen, B. O., and A. L. Boettcher, Melting of a hydrous mantle, $J$. Petrol., 16, 520-548, 549-593, 1975.

Perchuk, L. L., Thermodynamic control of metamorphic processes, in Energetics of Geological Processes, edited by S. K. Saxena and S. Bhattacharji, pp. 285-352, Springer, New York, 1977.

Ringwood, A. E., Composition and Petrology of the Earth's Mantle, McGraw-Hill, New York, 1975.
Rosenhauer, M., E. Woermann, B. Knecht, and G. C. Ulmer, The stability of graphite and diamond as a function of the oxygen fugacity in the mantle, paper presented at the Second International Kimberlite Conference, Santa Fe, N. Mex., 1977.

Solomon, S. C., Geophysical constraints on radial and lateral temperature variations in the upper mantle, Amer. Mineral., 61, 788-803, 1976.

Walker, D., E. M. Stolper, and J. F. Hays, A numerical treatment of melt/solid segregation: Size of the eucrite parent body and stability of the terrestrial low-velocity zone, J. Geophys. Res., 83, 6005-6013, 1978.

Woermann, E., B. Knecht, M. Rosenhauer, and G. C. Ulmer, The stability of graphite in the system $\mathrm{C}-\mathrm{O}$, paper presented at the Second International Kimberlite Conference, Santa Fe, N. Mex., 1977.

Wyllie, P. J., Mantle fluid compositions buffered by carbonates in peridotite- $\mathrm{CO}_{2}-\mathrm{H}_{2} \mathrm{O}$, J. Geol., 85, 187-207, 1977.

Wyllie, P. J., Mantle fluid compositions buffered in peridotite- $\mathrm{CO}_{2}-$ $\mathrm{H}_{2} \mathrm{O}$ by carbonates, amphibole, and phlogopite, J. Geol., 86, 687713, 1978.

Wyllie, P. J., Magmas and volatile components, Amer. Mineral., 64, 469-500, 1979.

Wyllie, P. J., and W. L. Huang, High $\mathrm{CO}_{2}$ solubilities in mantle magmas, Geology, 4, 21-24, 1976.

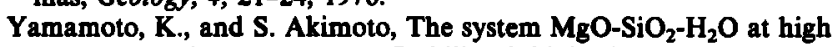
pressures and temperatures - Stability field for hydroxyl-chondrodite, hydroxyl-clinohumite and 10 A-phase, Amer. J. Sci., 277, 288312, 1977.
(Received March 5, 1980; revised March 27, 1980; accepted April 1, 1980.) 